\title{
ПОСЛЕДИЦЕ ПАНДЕМИЈЕ КОВИДА 19 ПО ЕКОНОМСКУ БЕЗБЕДНОСТ ГРАЪАНА РЕПУБЛИКЕ СРБИЈЕ
}

\author{
проф. др Ивица Ђорђевић ${ }^{1}$ \\ др Марко Филијовић²
}

Апстракт: За коначну анализу тока пандемије и њених последица још увек је прерано. Међутим, ми већ сада можемо да говоримо о видљивим ефектима ванредног стања по квалитет живота грађана и ниво привредних активности. Као аналитички оквир искористићемо концепт људске безбедности који се питањем безбедности грађана бави кроз анализу седам области битних за квалитет њихових живота. У свакој од седам димензија људске безбедности је на директан или индиректан начин дошло до одређених промена. После здравствене највидљивији су ефекти у економској димензији, која је у фокусу наше анализе. Због развијене методологије и начина обраде података ефекти пандемије се најпре региструју путем промене економских индикатора, за које су доступни и најобимнији статистички извори. О еколошким аспектима можемо да говоримо у позитивном контексту, док се политичка безбедност и безбедност заједнице, односно индивидуална безбедност, поред повезивања са здравственим ефектима, могу контекстуализовати у односу на ситуацију пре пандемије. Занимљива је корелација у наведеним областима у односу на претходна стања и праксу у политичкој сфери, односно безбедност заједнице. Повезивање претходног са актуелним стањем говори нам о недостацима у области људске безбедности, који у одређеним околностима могу да допринесу драстичном погоршању ситуације.

Кључне речи: Пандемија, ковид 19, људска безбедност, економија, квалитет живота.

1 Универзитет у Београду, Факултет безбедности; e-mail: djivica@gmail.com. Ставове и закључке изнесене у тексту не треба поистовећивати са односом институције према теми у којој је аутор запослен.

2 Атински институт за образовање и истраживање (Athens Institute for Education and Research - ATINER), Атина, Грчка. 


\section{УВОД}

Светска пандемија изазвана вирусом ковид 19 избацила је на површину многе слабости постојећих институционалних система, као и проблеме у функционисању Светске здравствене организације. Неприпремљеност и пропусти у раду указују на системске недостатке који су последица утицаја више фактора. Наведене организације биле су успаване дугим периодом релативно стабилне ситуације иако су постојали наговештаји о могућим појавама пандемија глобалних размера. Под притиском рационализације оскудних буџетских средстава редуковане су активности које су предуслов успешног суочавања са последицама масовног оболевања становништва. Супротно расту посведоченом економским статистичким показатељима, није обезбеђен квалитативни развој системаิ који треба да пруже бенефите од повећаног обима глобалних економских активности.

Концепт људске безбедности (КљБ) је настао са идејом да се путем анализе система и уочених недостатака у његовој структури превентивно делује. Стиче се утисак да је због идеолошких разлога дошло до опструкције операционализације и његове примене у пракси. Истраживачи из неких развијених земаља више су се бавили интелектуалним вежбама на тему дефиниције и методологије него потенцијалом КљБ за практично деловање. Стиче се утисак да је пропуштена шанса за еволутивним корекцијама - реформом система у односу на нове околности, што је била и основна интенција истраживача који су учествовали у писању извештаја Програма за развој Уједињених нација (United Nations Development Programme - UNDP) за 1994. годину. ${ }^{3}$

\section{КОНЦЕПТ ЉУДСКЕ БЕЗБЕДНОСТИ}

Концепт људске безбедности је промовисан од стране UNDP након уочених негативних трендова у односу на постојеће државне институције према интересу грађана. Креатори концепта су покушали да скрену пажњу на неопходност глобалних институционалних реформи како би се заштитила права грађана од негативних ефеката уочених аномалија. Стихијност глобалних процеса доводи до ретроградних појава у односу на достигнуте и прокламоване стандарде у поштовању људских права на планетарном нивоу. Инструментализација постојећих институција зарад реализације интереса крупног капитала уместо подизања свеопштег нивоа благостања довела је до драстичног раста разлика између добитника и губитника глобализације. Са одустајањем од механизама контроле монополизације економских активности створени су услови за енормну концентрацију капитала под управом малог броја најбогатијих. Количина новца

3 UNDP, Human Development Report 1994 - New Dimensions of Human Security, Oxford University Press, New York - Oxford, 1994. 
коју контролише светска финансијска олигархија у постојећем систему који се базира на профиту као јединој мери вредности овима даје неограничену моћ. ${ }^{4}$

Диспропорција која је створена у корист приватних фондова државне институције доводи у инфериорни положај. Захваљујући контроли медијског простора, власници капитала креирају политички амбијент по мери својих интереса. ${ }^{5}$ Корумпиране политичке структуре нису у стању да обезбеде нормално функционисање институционалног система, што се најбоље види у условима ванредних ситуација као што су поплаве и пожари. Због неадекватне материјалне и кадровске опремљености дешавају се колапси система. Лоше реаговање у ванредним ситуацијама, односно неспособност да се схвати неопходност промена у цивилизацијским обрасцима понашања гурају човечанство ка ивици иза које више није могуће преокренути трендове које је човек покренуо својим негативним утицајем на природне механизме саморегулације.

КљБ је постављен тако да путем секјуритизације седам димензија битних за квалитет живота људи на планети путем квантификације стања скрене пажњу на описане трендове и покрене грађане и институције на акцију. Глобални трендови се пресликавају на ниво националних држава, при чему треба нагласити да најгоре пролазе државе које спадају у категорију тзв. земаља у развоју (ЗУР), односно неразвијене земље. Мале неразвијене земље су приморане да прихватају неповољне аранжмане са контролорима транснационалног капитала, улазећи у тзв. утакмицу суманутих, такмичећи се ко ће понудити јефтинију радну снагу и повољније услове за рад експозитура ТНК. Та ситуација доводи до успостављања неоколонијалног односа и одлива ионако оскудних средстава из ЗУР према развијеним земљама. Смањење прилива новца у буџете ЗУР утиче на ниво расположивих средства за улагање у развој јавних служби, што се одражава и на функционалност здравствених система. Треба скренути пажњу да ни развијене земље нису поштеђене логике деловања којему су изложене ЗУР. Управљачи крупног капитала немају милости ни према коме, јер капитал не препознаје националност или неку другу врсту припадности. Основни циљ максимизације профита остварује се уз употребу свих погодности неконтролисаног глобалног простора који је ван националних јурисдикција. ${ }^{6}$

Идеја о квантификацији безбедности људи на неком простору путем 7 димензија и одговарајућих индикатора унутар сваке од њих који треба да дају информације

4 Ивица Ђорђевић, Безбедносна архитектура у условима глобализације, Факултет безбедности и Службени гласник, Београд, 2007; Бранко Милановић, Глобална неједнакост, Академска књига, Нови Сад, 2016.

5 - UNCTAD, Trade and Development Report 2018 / Report by the secretariat of the United Nations Conference on Trade and Development, United Nations, New York and Geneva, 2018. 14/08/2020; Ивица Љ. Ђорђевић, Марко Филијовић: „Улога Медија у реализацији пројекта културног империјализма“, Зборник Матище српске за друштвене науке, Vol. 147, No.2, 2014, стр.281-294.

6 Ивица Љ. Ђорђевић, Људска безбедност - глобални контекст и примена у Србији, Институт за упоредно право и Досије студио, Београд, 2013. 
о квалитету живота грађана представља виши ниво анализе у односу на националну (и/или државну) безбедност. Сама идеја можда није у потпуности оригинална, али је по први пут покушана њена операционализација путем заокруженог теоријског модела7 ${ }^{7}$ одговарајуће матрице ${ }^{8}$ која је развијана од стране многих хуманистички оријентисаних истраживача. Поменута група истраживача је препознала потенцијал КљБ и радила на његовој операционализацији. Посебно наглашавамо да у анализама родоначелника КљБ не постоји антагонизам између класичних система безбедности и КљБ, сем у ситуацијама када су полуге система инструментализоване од стране уских интересних група. КљБ се појављује као корективни механизам у случајевима када класични безбедносни механизми нису у стању да обављају своје функције.

Чињеница је да највећи број ЗУР има проблем са великим диспропорцијама у расподели друштвеног богатства, што је све више уочљиво и у развијеним западним земљама. КљБ показује кроз конкретне податке размере проблема и разбија предрасуде о нужно позитивним ефектима глобалног раста кроз период тзв. хиперглобализације од 1989. до 2008. године. Изостанак развојне компоненте доводи до тога да упркос статистички забележеном економском расту опада квалитет живота већине људи на планети . То се најбоље региструје путем истраживања ставова грађана о њиховом статусу и односу према функционисању система. Према истраживању Европске банке за обнову и развој расположење грађана транзиционих земаља у односу на демократију (онаквом са којом се они сусрећу у пракси) на силазној је путањи. ${ }^{9}$

Здравствени системи већине савремених земаља под притиском рационализације нису у стању да одговоре захтевима ситуације. Још почетком 2000-их постојала су упозорења о томе да здравствени систем САД није у стању да се суочи са новом пандемијом размера попут оне узроковане великим богињама. ${ }^{10}$ Због отпора реформи здравственог система од стране неоконзервативних кругова ништа није учињено да се уочени недостатак отклони. Под притиском Вашингтонског консензуса и здравствени системи транзиционих земаља су такође девастирани. Међутим, занимљиво је да су и поред тога остаци некадашњих система већине некадашњих социјалистичких (комунистичких) земаља боље реаговали на појаву пандемије изазване вирусом ковид 19 него у далеко богатијим земљама Запада. 11

7 UNDP, Human Development Report 1994 - New Dimensions of Human Security, Oxford University Press, New York - Oxford, 1994.

8 UN, HUMAN SECURITY HANDBOOK - An integrated approach for the realization of the Sustainable Development Goals and the priority areas of the international community and the United Nations system, United Nations - Human Security Unit, New York, 2016.

9 Ивица Љ. Ђорђевић, Људска безбедност - глобални контекст и примена у Србији, Институт за упоредно право и Досије студио, Београд, 2013, стр.146. На основу: EBRD, Life in Transition, After the Crisis, European Bank for Reconstruction and Development, London, 2011, p. 22.

10 Amy Maxmen \& Jeff Tollefson, „Two decades of pandemic war games failed to account for Donald Trump", Nature Research, Vol. 04, August 2020, Springer Nature Limited, https://www.nature.com/articles/d41586-020-02277-6, 14/09/2020.

11 WHO, „Coronavirus Disease (COVID-19) Dashboard“, Data last updated: 2020/9/16, 11:44am CEST, World Health Organization, 
КЉБ указује на значајну корелацију која постоји између здравствене ситуације и стања у области исхране. ${ }^{12}$ Показало се да индустријализација производње хране и повећање учешћа брзе хране у исхрани значајно утиче на здравствени билтен нација. Навике у исхрани и квалитет намирница су неодвојиви од стања здравља нација.

У КљБ значајно место заузима утицај животног и радног окружења на квалитет живота. Хуманисти указују на проблем који је последица ситуације да свака идеја о очувању планете као животног станишта наилази на велики отпор профитних центара моћи, који врше опструкцију примене међународних декларација и конвенција о заштити природе. Због климатских промена људи су све више изложени негативним утицајима глобалног отопљавања. Појава пожара који уништавају велике површине под шумама додатно компликују ионако сложену ситуацију. Ауторима ових редова није јасно зашто се не ангажују додатна расположива техничка средства (канадери) за гашење пожара и дозвољава да милиони хектара годишње изгоре. Због занемаривања проблема настаје двострука штета: уништавају се плућа планете и повећава количина угљеника у атмосфери.

Очигледна дисфункционалност система окреће људе ка алтернативама које су најчешће у виду фундаменталистичких покрета (екстремне: левице, деснице или разне форме верског организовања). Неповерење у систем се одражава и на процентуално учешће у политичком животу, односно спремност да се људи активно укључе у решавање проблема из непосредног окружења. На индивидуалном нивоу постоје изазови које централизована власт није у стању да решава с обзиром на квалитет кадрова које може да ангажује и расположива средства. Буџети за јавне службе су све сиромашнији због одрицања од прихода које држава чини кроз уступке крупном капиталу. ${ }^{13}$

Војне и полицијске структуре су све чешће у функцији заштите интереса крупног капитала него у вршењу њихове оригиналне улоге. Случајеви злоупотребе идеје о заштити људских права су потпуно дезавуисали поверење у међународну заједницу и покушај успостављања глобалне управе. Количина новца који се окреће у војној индустрији не оставља простора за хуманизам. Инсценирају се ситуације које служе за оправдавање војних интервенција у циљу контроле простора или једноставно отварања нових тржишта за продају оружја. ${ }^{14}$

Из ове перспективе гледано свет се налази пред провалијом и питање је да ли постоји снага и начин да се тај тренд заустави. С обзиром на то да су хегемонистичке снаге (глобалне структуре моћи) учиниле доста тога да сваку идеју хуманизације цивилизације искомпромитују, односно смање изгледе за њихову реализацију, ситуација нимало није сјајна. Због тога је значај КљБ још

https://covid19.who.int/?gclid=EAIaIQobChMIlpigt9Pt6wIVDNOyCh3aEwj5EAAYASAAEgJTgf D_BwE, 16/09/2020.

12 Barry M. Popkin, Linda S. Adair, and Shu Wen Ng, „Global Nutrition Transition: The Pandemic of Obesity in Developing Countries", Nutrition Reviews, Volume 70, Issue 1, 2012, https://academic.oup.com/nutritionreviews/article/70/1/3/1829225, 14/09/2020, pp. 321.

13 Ивица Ђорђевић и Зоран Јефтић, „Промена финансијског положаја државе као безбедносни проблем“, Међународни проблеми, Vol. LXVIII, No.2-3, 2016, стр.194.

14 Довољно је подсетити на примере попут: Ирака, Либије и Сирије. 
већи, јер снагом аргумената може да утиче на промену свести о проблемима савремене цивилизације.

\section{ЕФЕКТИ ПАНДЕМИЈЕ ИЗАЗВАНЕ ВИРУСОМ КОВИД 19}

Карактеристике пандемије и њен обухват чине је по могућим (и тренутно реалним) ефектима првом правом глобалном економском кризом од 1929. године. Чак и криза из 2008. године била је ограничена на финансијски сектор најразвијенијих земаља, те су њени ефекти ублажени високим растом привредних активности у Кини и у земљама у развоју. Негативних економских ефеката корона пандемије нико није поштеђен. Пад економских активности у условима пандемије показао је како глобализација, толико хваљена у условима раста, даје хаотичне резултате када дође до кризе без адекватних регулаторних механизама. Корона се брзо проширила користећи све погодности глобалних транспортних мрежа, док на другој страни није било адекватног одговора, што је и довело до глобалне кризе. Чак и земље које су потпуно ван глобалних привредних токова, односно са минималним учешћем у светској трговинској размени, трпе негативне ефекте због актуелне пандемије. Према проценама Светске банке преко 60 милиона људи ће бити изложено условима екстремног сиромаштва због последица пандемије изазване вирусом ковид 19. Поред погодности за ширење пандемије, отворене границе додатно отежавају положај земаља у развоју, које су своју привредну структуру везивале за глобално тржиште, односно стварале структуру која је зависна од страних инвестиција и дистрибутивних ланаца великих ТНК. Са кризом долази до повлачења активности према централи, тако да највишу цену кризе плаћају експозитуре у ЗУР. Повлачење капитала и обустављање производних активности изазива проблеме не само у сфери економије већ доприноси и социјалној нестабилности која је ионако крхка у већини ЗУР. Ситуација погодује појави разних популистичких и десничарских покрета који виде прилику за своју промоцију и њихов повратак на политичку сцену. Општа друштвена клима умногоме подсећа на ситуацију уочи Другог светског рата. 15

Ефекти пандемије нису ограничени само на сектор здравља и привреду; посредно због заштите јавног здравља предузете мере утичу и на социјалне, али и политичке прилике. Предузимање непопуларних мера у циљу сузбијања ширења вируса изазива опречне реакције у политичкој сфери. Поставља се питање да ли су предузете адекватне мере у право време и одговарајућег интензитета. У пракси је било различитих примера: од почетног несналажења због непознавања праве природе вируса па до коришћења прилике да се намакне неки политички поен, што је доводило до огорчених реакција у јавности у облику протеста и промовисања разних теорија завере путем интернета.

Од почетног драстичног прекида свих активности, како је време одмицало, схватало се да живот мора да настави даље и да је неопходно одржање

15 Carmen Reinhart and Vincent Reinhart, „The Pandemic Depression The Global Economy Will Never Be the Same", Foreign Affairs, September/October 2020, https://www.foreignaffairs.com/articles/united-states/2020-08-06/coronavirus-depressionglobal-economy, 18/09/2020. 
привредних активности на минимуму који омогућава функционисање система за време короне, али и што бржи повратак у нормалу након што пандемија прође. Неке делатности не могу да прекину са радом и њих Глигоров сврстава у вирусну привреду (производња хране, трговине, здравство...), док неке прелазе у виртуелни свет и чекају нормализацију ситуације (престанак пандемије) како би се вратиле у нормалу (ИТ сектор, образовање...). ${ }^{16}$

\section{ЕКОНОМСКА СИТУАЦИЈА У РЕПУБЛИЦИ СРБИЈИ}

Негативне последице ширења вируса ковид 19 евидентне су широм света, па тако и у Републици Србији. У том смислу требало би истаћи да је Република Србија кризу изазвану пандемијом дочекала са снажном фискалном позицијом (захваљујући активностима на фискалној консолидацији у претходним годинама), солидним растом (од 4,2 одсто у 2019. години), ниском незапосленошћу $\left(10,4\right.$ одсто) и ниском инфлацијом. ${ }^{17}$ Па ипак, и поред повољних показатеља, различити извештаји процењују да ће Србија, као и многе друге земље, у току 2020. године ући у рецесију.18 За то постоји више разлога. Наиме, према анализи Организације за економску сарадњу и развој (Organisation for Economic Co-operation and Development - OECD), спроведеној 27. марта 2020. године, због избијања епидемије 168 производних компанија у Србији привремено је зауставило производњу, 67.000 запослених радило је од куће, док су многи ланци снабдевања прекинути. Губици у области инфраструктуре и транспорта од избијања епидемије до 17. марта премашили су 110 милиона евра, при чему су у области туризма само у периоду од почетка марта до прве половине априла они достигли износ од 2,7 милиона евра. Када је реч о негативним ефектима пандемије по финансијско тржиште, довољно је истаћи да је у периоду између 10. јануара и 14. априла BELEX15 индекс изгубио 20 одсто своје вредности, а да је домаћа валута депресирала око 3 одсто од почетка године, што, како истичу креатори поменуте студије, „сигнализира потенцијални одлив капитала и отежава међународне трговинске и инвестиционе одлуке“.19

16 Владимир Глигоров, „Опоравак после епидемије у Хрватској и Србији“, Рег̌̌́anik, 14/07/2020, https://pescanik.net/wp-content/uploads/2020/07/corona.pdf, str.2, $28 / 08 / 2020$.

17 WB, Ekonomski i socijalni uticaj COVID-19, Zapadni Balkan - Redovni ekonomski izveštaj br. 17, proleće 2020, World Bank Group,

http://pubdocs.worldbank.org/en/895931588364704429/WB-RER-17-All-Country-NotesSerbian.pdf, 14/06/2020, str. 37-38.

18 - OECD, Tackling Coronavirus (COVID-19) - Contributing to a Global Effort - The COVID-19 Crisis in Serbia, 27 April, and 8 June 2020; Organisation for Economic Co-operation and Development, https://www.oecd.org/coronavirus/en/\#country-tracker, 28/08/2020.

- WB, Fighting COVID-19. Europe and Central Asia Economic Update, Office of the Chief Economist, Spring 2020, World Bank,

https://openknowledge.worldbank.org/bitstream/handle/10986/33476/9781464815645.p df, $14 / 06 / 2020$.

${ }^{19}$ OECD, op. cit., 27 April, 2020, pp. 1-2. 
Целокупној негативној слици српске економије доприноси и очекивање да ће се прилив страних директних инвестиција видно смањити, као и домаће инвестирање, те да ће доћи до осетног пада дознака из иностранства, што може довести до даљег смањења потрошње. Такође, постоји процена да ће се чак 85 одсто малих и средњих предузећа наћи под негативним утицајем вируса ковид 19.20 То између осталог веома убедљиво потврђује и једно истраживање спроведено у периоду између 25. и 29. марта 2020. године, у којем је учествовало 209 микро и малих предузећа са територије Републике Србије. Наиме, подаци из студије показују да 85 одсто микро и малих предузећа процењује да ће пандемија имати негативан утицај на њихово пословање. Око 80 одсто њих очекује смањење потражње за производима и услугама током и након трајања пандемије, док је око 30 одсто предузећа мишљења да ће се то одразити на смањење броја запослених у истим. Осим тога, преко 70 одсто предузећа очекује да ће осећати економске последице пандемије на пословање 6 месеци и дуже, а 48 одсто процењује да ове изазове неће моћи да превазиђе без додатне подршке. Конкретно, „на питање колико предузеће може да преживи на тржишту са тренутним резервама и без додатних прихода, 37,8 одсто испитаних предузећа је одговорило да може да преживи до три месеца, 34,9 одсто од 15 до 30 дана, 14,8 одсто до 15 дана, 8,1 одсто до шест месеци, и само 1,4 одсто до годину дана. На питање да ли ће предузеће бити у стању да настави са стратешким плановима и пројектима који су започети у овој години, 40,2 одсто предузећа је одговорило негативно, 14,4 одсто позитивно, док 42,1 одсто није сигурно“.21 Ово истраживање у великој мери потврђује и налазе експерата Организације за економску сарадњу и развој који су дошли до податка да „удео фирми које су драстично смањиле своје производне капацитете износи око 60,5 одсто“, а „удео оних које очекују потешкоће у покривању рачуна око 91 одсто“.22 Ако се уз то дода информација Привредне коморе Србије да је до 31. марта 2020. године око 77.000 радника било на принудном одмору због прекида производње, а 1000 фирми имало блокиране рачуне због немогућности плаћања рачуна, јасно је под коликим притиском су се нашла српска предузећа. ${ }^{23}$

Имајући у виду актуелну ситуацију, Светска банка (World Bank) израдила је неколико сценарија за Србију. Према првом, повољнијем сценарију српски БДП ће се смањити 2,5 одсто у 2020. години. У том случају, опоравак би могао да почне у другој половини године, а утицај пандемије на економију разликовао би се по секторима. Најпогођенија би била индустријска производња, с пројектованим падом од 9 одсто, док би услуге такође биле погођене, али у различитом степену. Наиме, транспорт и туризам би претрпели највећи удар, при чему би услуге забележиле пад од око 1

20 OECD, op. cit., 8 June, 2020, p. 2.

${ }^{21}$ Смарт колектив и Форум за одговорно пословање, Последище пандемије корона вируса на пословање малих и микро предузећа у Србији, Beograd, 2020., str. 4-7, https://smartkolektiv.org/aktuelnosti/analiza-posledice-pandemije-na-poslovanje-mikro-imalih-preduzeca-u-srbiji/, 14/06/2020, str. 4-7.

22 OECD, op. cit., 8 June, 2020, p. 2.

${ }^{23}$ WB, Tržišta rada i šok izazvan kovidom-19 na Zapadnom Balkanu, 2020, World Bank Group, http://documents.worldbank.org/curated/en/318211590693118258/pdf/The-Economicand-Social-Impact-of-COVID-19-Labor-Markets.pdf, 14/06/2020. 
одсто. Како се наводи у извештају Светске банке: „Дешавања у реалном сектору ће утицати на спољни рачун и фискалну позицију. Очекује се да ће се трговина робом знатно смањити у еврима: извоз робе за 12 одсто и увоза за 17,8 одсто. Извоз у секторима транспорта и туризма био би мањи за око 30 одсто, а очекује се пад дознака за око 20 одсто. Као резултат такве ситуације у 2020. години би дефицит текућег рачуна могао порасти и достићи око 7 одсто БДП-а. Фискални дефицит би могао достићи 7,3 одсто БДП-а, јер се очекује пад прихода од 3,3 одсто БДП-а у склопу најављеног фискалног пакета и повећање потрошње од око 3,5 одсто. Јавни дуг би до краја године могао достићи 63,9 одсто БДП-а“.24

С друге стране, негативни сценарио предвиђа пад БДП-а од 5,3 одсто. Он подразумева дуже трајање пандемије, што би довело до каснијег успостављања ланаца снабдевања и споријег опоравка услужног сектора. Како се наводи у поменутом извештају, у том случају: „На страни потрошње све компоненте БДП-а би имале стрмији пад, нарочито извоз и потрошња. Фискални дефицит би достигао 8,6 одсто БДП-а, јер би приходи додатно опали, а повећала би се потрошња за социјалне трансфере, чиме би јавни дуг достигао раст од 69,1 одсто БДП-а. Слично томе, биланс плаћања би се погоршао, а дефицит текућег рачуна би достигао 9,3 одсто БДП-а“ (табела 1). Према овом сценарију, рецесија би била дубља, а фискални и спољни притисци израженији, при чему би главни аспект представљала „забринутост да инвеститори буду мање спремни за преузимање ризика, што би повећало трошкове задуживања и створило додатни притисак и на фискалне и на спољне рачуне“.25

Табела 1. Могући сценарији за Републику Србију у 2020. години

\begin{tabular}{|l|c|c|c|}
\hline & $\begin{array}{c}\text { Оригиналне } \\
\text { (првобитне) } \\
\text { пројекције }\end{array}$ & $\begin{array}{c}\text { Нови основни } \\
\text { сценарио (y } \\
\text { случају нове } \\
\text { основице) }\end{array}$ & $\begin{array}{c}\text { Неповољнији } \\
\text { сценарио (ниска } \\
\text { основица) }\end{array}$ \\
\hline $\begin{array}{l}\text { Реалне стопе } \\
\text { раста }\end{array}$ & 3.9 & & -5.3 \\
\hline БДП & 5.7 & -2.5 & -3.5 \\
\hline Потрошња & 5.3 & -2.3 & -7.7 \\
\hline Инвестиције & 4.9 & -5.2 & -18.5 \\
\hline Увоз & 7.6 & -10.2 & -15.1 \\
\hline Извоз & -9.7 & \\
\hline
\end{tabular}

Извор: WB, Ekonomski i socijalni uticaj COVIDA-19, Zapadni Balkan - Redovni ekonomski izveštaj br. 17, proleće 2020, World Bank Group,

http://pubdocs.worldbank.org/en/895931588364704429/WB-RER-17-All-CountryNotes-Serbian.pdf, 14/06/2020.

24 WB, Ekonomski i socijalni uticaj COVID-19, Zapadni Balkan - Redovni ekonomski izveštaj br. 17, proleće 2020, World Bank Group,

http://pubdocs.worldbank.org/en/895931588364704429/WB-RER-17-All-Country-NotesSerbian.pdf, 14/06/2020.

25 WB, Ekonomski i socijalni uticaj COVID-19, Zapadni Balkan - Redovni ekonomski izveštaj br. 17, op. cit., str. 32 . 
Иако су ове процене у суштини неповољне, требало би ипак истаћи да је по појединим параметрима, као што је нпр. кретање БДП-а, Србија боље позиционирана у пројекцијама Светске банке него многе државе у њеном окружењу (графикон 1.).

Након првих ефеката пандемије, када је због рестриктивних мера кретања дошло до стагнације, а у неким областима и потпуног прекида, у мају је након ублажавања здравствених мера дошло до благог опоравка привредних активности. Према подацима Народне банке Србије дошло је до пада од 6,5\% БДП у односу на исти период из претходне године, што је за 1,5\% бољи резултат од прогнозираног на основу ситуације након првог таласа пандемије у Републици Србији. Овај тренд је забележен највише захваљујући прерађивачкој индустрији, док су гране попут туризма, угоститељства и транспорта и даље у дубоком минусу у односу на претходну годину. Због предузетих мера Владе није забележен значајнији пад формалне запослености; међутим, треба имати у виду да су многи привремени и повремени послови обустављени, што свакако утиче на стандард становништва. Предузете мере подразумевају непланирано издвајање из буџета, што у комбинацији са смањеним приливом средстава доводи до дефицита који је покривен задуживањем на међународном финансијском тржишту и емитовањем динарских хартија од вредности, што је укупно довело до повећања јавног дуга на $57 \%$ од БДП, уз процену да ће достићи 60\% до краја године. ${ }^{26}$

Графикон 1. Пројектовани повољни и неповољни сценарији везани за раст БДП-а код балканских земаља 27

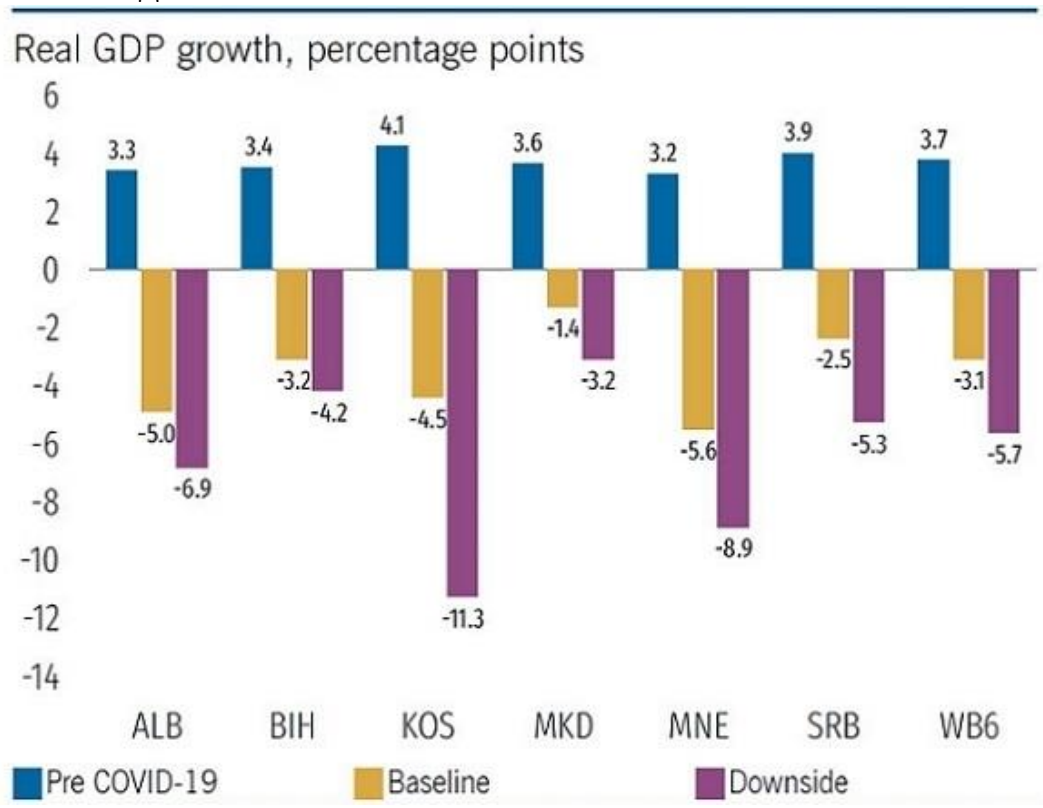

26 НБС, Извештај о инфлацији, август 2020, Народна банка Србије, https://www.nbs.rs/internet/cirilica/90/ioi.html, 27/08/2020.

27 WB, Serbian Economy Shrinks as Country Responds to COVID-19, Press Release, 29. April, 2020, World Bank, https://www.worldbank.org/en/news/press-release/2020/04/29/serbianeconomy-shrinks-as-country-responds-to-covid-19, 14/06/2020 
Предузете мере у склопу антикризне политике су оправдале своју функцију и у складу су са економском теоријом, односно на исти начин се против негативних ефеката пандемије боре и остале државе света. У датом контексту забрињавајући је тренд који се бележи на глобалном нивоу, односно општи пад привредних активности. С обзиром да је Република Србија значајан део својих привредних планова и капацитета везала за стране инвестиције и зависна је од кретања на тржиштима њених највећих спољнотрговинских партнера, ефекти предузетих мера и даљи развој догађаја не зависе само од унутрашње политике. У Европској унији, која је по подацима Републичког завода за статистику са учешћем у спољнотрговинској размени од 61,8\% највећи трговински партнер, забележен је пад БДП у другом кварталу ове године од $12,1 \%$. У земљама са којима Република Србија највише сарађује: у Немачкој тај пад је 10,1\% и Италији 12,1\%.28

Анализи треба додати и информацију да су међу највећим извозницима из Србије компаније које су везане за аутоиндустрију (Фијат - FCA Srbija DO0, Тигар - Tigar Tyres, Jypa - Yura Corporation...) и железара Смедерево (HBIS Group Serbia Iron \& Steel D00). ${ }^{29}$ У условима кризе тражња најпре реагује смањењем за производима који се могу окарактерисати као луксуз и долази до смањења инвестиционих улагања, односно одлаже се обнављање возног парка и градње нових објеката. ${ }^{30}$ Зато можемо очекивати додатно смањење извоза и повећање дефицита у међународној размени Србије, што упућује на потребу за опрез при пројектовању будућих трендова. Ова напомена добија на значају када се има у виду процењена дужина периода опоравка од актуелне кризе која може потрајати и до 7 година.

\section{ЗАКЉУЧАК}

Пандемија изазвана вирусом ковид 19 довела је до поремећаја у постојећем моделу функционисања савремене цивилизације и по својим ефектима је свеобухватна у односу на безбедносни статус грађана. Као што смо рекли да многи институционални аспекти доприносе ширини и дубини појаве, тако и ефекти пандемије могу да се посматрају кроз све аспекте квалитета живота грађана који су препознати у концепту људске безбедности као релевантни за утврђивање нивоа безбедности становништва на неком простору. Пад економских активности је довео до економске кризе у глобалним размерама, али ефекте тога треба посматрати у контексту сваке заједнице (државе, региона) са свим њиховим специфичностима. Смањење привредних активности довело је до општег раста незапослености. Тамо где су предузете одговарајуће стимулативне мере од стране

28 Тања Вујић, „Рекордан пад привреде САД и еврозоне“, Политика, 1. август, 2020.

29 Министарство Финансија Републике Србије, ТЕКУЋА МАКРОЕКОНОМСКА КРЕТАњА, септембар 2020, https://www.mfin.gov.rs/wpcontent/uploads/2020/09/prezentacija_novo_sr-pdf.pdf, 18/09/2020.

30 ILO, Sectoral impact, responses and recommendations, International Labour Organization, Genève, 2020,

https://www.ilo.org/global/topics/coronavirus/sectoral/lang--en/index.htm, 27/08/2020. 
локалних влада, још увек није дошло до значајнијег отпуштања радника, али поставља се питање колико државе могу да интервенишу с обзиром на то да су смањени буџетски приходи. Посебно су угрожени грађани који су радили на привременим и повременим пословима који су били први на удару кризе.

С обзиром на глобалну повезаност националних привреда, можемо рећи да су и ефекти пандемије глобални, почев од тога да је покретљивост људи као туриста и радне снаге у транснационалним пословним ланцима убрзала ширење пандемије, па до тога да су негативни ефекти смањења привредних активности видљиви на планетарном нивоу. Ситуација у Републици Србији са пандемијом изазваном вирусом ковид 19 не разликује се пуно у односу на глобалне трендове. С обзиром на глобалну повезаност националних привредних система, можемо да приметимо да су земље са нижим нивоом глобализованости својих привреда у датим околностима мање погођене кризом. Свакако да негативни трендови из привреда земаља наших највећих трговинских партнера имају утицаја на привредне билансе Републике Србије, али ти ефекти могу донекле да буду ублажени мерама владе.

Пандемија је открила многе недостатке постојећег модела организације друштвеноекономских активности базираног на логици неоконзервативног тумачења економских процеса. Показало се да би без интервенција националних држава дошло до тоталног колапса на глобалном нивоу. Помоћ најугроженијима је била у фокусу свих, па и САД, које су доскора биле промотер неолибералне економске догме. Ситуација је такође показала да капацитети приватних здравствених система нису довољни за реаговање у условима масовног оболевања становништва. Пандемија је такође поново актуелизирала етичко питање односа према грађанима који нису у систему здравствене заштите. Социјална солидарност такође постаје актуелна у односу на део угрожене популације становништва који је због пада привредних активности још више погођен сиромаштвом.

Због објективности у анализи морамо да поменемо и пар позитивих ефеката пандемије. Наиме, поред смањења загађења животне средине, дошло је и до пада класичних криминалних активности, док је високо технолошки криминал добио на замаху. Економска криза је увек повезана са растом разних облика криминалних активности. Недостатак средстава из легалних извора прихода један део популације покушава да надокнади кроз разне форме илегалних делатности. Међутим, према подацима Министарства унутрашњих послова (МУП) Републике Србије види се да је током трајања ванредног стања забележен знатан пад стопе криминала у односу на исти период прошле године. Тачније, у периоду од 15. марта до 1. маја забележно је око 60 одсто мање кривичних дела него у истом периоду претходне године. ${ }^{31}$ Ова појава може да се објасни увођењем забране кретања, што је грађане оставило у становима, а криминалце такође

31 Данијела Вукосављевић, „Током ванредног стања забележен пад криминала од 60 одсто“ Политика, 18.05.2020, http://www.politika.rs/sr/clanak/454357/Tokom-vanrednog-stanja-zabelezen-padkriminala-od-60-odsto, 18/6/2020. 
приморало да се одрекну својих „послова“. За разлику од класичног криминала, у Србији је дошло до пораста високотехнолошког криминала, превара на интернету и сексуална експлоатације за онлајн услуге. ${ }^{32}$

Овом приликом треба нагласити како су многи негативни ефекти пандемије могли бити избегнути да су институције система радиле свој посао у складу са њиховом прокламованом друштвеном функцијом. Пандемија је указала на многе проблеме који су у фокусу КљБ, тако да је ово прилика да се стручна и научна јавност поново подсете на његове основне поставке. Још увек није дошао тренутак за коначни биланс пандемије, овом приликом подсећамо да је врло битан детаљ концепта људске безбедности узимање у обзир субјективних осећаја грађана у односу на реалне околности. Поред постојећих пројекција економиста и оптимизма (односно песимизма) стручне јавности, важан аспект економских ефеката пандемије представља и перцепција људи о последицама ширења вируса ковид 19. У том смислу вредно је истаћи истраживање агенције „Валикон“, спроведено у периоду март-мај 2020. године на простору Балкана. Оно је интересантно због чињенице што забринутост грађана Републике Србије за ширење епидемије изазване коронавирусом, иако смањена за чак $20 \%$ у односу на крај марта, остаје највиша у региону и износи 70\%, у поређењу са 47\% у Словенији, 58\% у Босни и Херцеговини (БиХ) и 62\% у Хрватској. Супротно томе, забринутост за економске последице једино је у Србији мања од половине и износи 40\%, док економске последице епидемије брину 69\% грађана Словеније, 61\% грађана БиХ и 59\% грађана Хрватске. ${ }^{33}$ Наведено истраживање показује да су грађани Републике Србије далеко више забринути за своје и здравље чланова породице него за економске последице.

На крају треба указати на опасност која прети од корупције као последице економске кризе изазване вирусом ковид 19. Снижавање реалних прихода и уочени благи инфлаторни тренд могу представљати окидач за раст корупције у државним структурама, чему систем мора озбиљно да се супротстави. Раст корупције може да поништи све анти-кризне мере које држава у датим околностима предузима.

\section{ЛИТЕРАТУРА}

- Valicon, „Regionalno istraživanje: BH građani najmanje optimistični u regiji po pitanju širenja korona virusa“, Agencija za savetovanje i istraživanje tržišta,

32 Танјуг, „Европол: У време корона кризе расту криминал и педофилија“, Новости, 2.4.2020,

https://www.novosti.rs/vesti/planeta.299.html:856876-Evropol-U-vreme-korona-krizerastu-kriminal-i-pedofilija, 18/6/2020.

33 Valicon, „Regionalno istraživanje: BH građani najmanje optimistični u regiji po pitanju širenja korona virusa", Agencija za savetovanje i istraživanje tržišta, 8.4.2020, https://www.valicon.net/bs/2020/04/regionalno-istrazivanje-valicona-bh-gradaninajmanje-optimisticni-u-regiji-po-pitanju-sirenja-korona-virusa/, 14/06/2020. 
08.04.2020, https://www.valicon.net/bs/2020/04/regionalno-istrazivanje-valiconabh-gradani-najmanje-optimisticni-u-regiji-po-pitanju-sirenja-korona-virusa/

- Вукосављевић, Данијела. „Током ванредног стања забележен пад криминала од 60 одсто“ Политика, 18.05.2020, http://www.politika.rs/sr/clanak/454357/Tokom-vanrednog-stanja-zabelezen-padkriminala-od-60-odsto, 18/6/2020.

- WB, Ekonomski i socijalni uticaj COVID-19, Zapadni Balkan - Redovni ekonomski izveštaj br. 17, proleće 2020, World Bank Group,

- http://pubdocs.worldbank.org/en/895931588364704429/WB-RER-17-All-CountryNotes-Serbian.pdf

- WB, Tržišta rada i šok izazvan kovidom-19 na Zapadnom Balkanu, 2020, World Bank Group,

http://documents.worldbank.org/curated/en/318211590693118258/pdf/The-

Economic-and-Social-Impact-of-COVID-19-Labor-Markets.pdf

- WB, Fighting COVID-19. Europe and Central Asia Economic Update, Office of the Chief Economist, Spring 2020, World Bank, https://openknowledge.worldbank.org/bitstream/handle/10986/33476/97814648 15645.pdf

- WB, Serbian Economy Shrinks as Country Responds to COVID-19, Press Release, 29. April, 2020, World Bank, https://www.worldbank.org/en/news/pressrelease/2020/04/29/serbian-economy-shrinks-as-country-responds-to-covid-19

- WHO, „Coronavirus Disease (COVID-19) Dashboard“, Data last updated: 2020/9/16, 11:44am CEST, World Health Organization, https://covid19.who.int/?gclid=EAIaIQobChMIlpigt9Pt6wIVDNOyCh3aEwj5EAAYAS AAEgJTgfD_BwE

- Вујић, Тања. „Рекордан пад привреде САД и еврозоне“, Политика, 1. август, 2020.

- Глигоров, Владимир. „Опоравак после епидемије у Хрватској и Србији“, Pešс̌anik, 14/07/2020, https://pescanik.net/wp-content/uploads/2020/07/corona.pdf.

- Ђорђевић, Ивица. Безбедносна архитектура у условима глобализације, Факултет безбедности и Службени гласник, Београд, 2007;

- Ђорђевић, Ивица Љ. Људска безбедност - глобални контекст и примена у Србији, Институт за упоредно право и Досије студио, Београд, 2013.

- Ђорђевић Ивица, Филијовић Марко, „Улога Медија у реализацији пројекта културног империјализма“, Зборник Матице српске за друштвене науке, Vol. 147, No. 2, 2014, стр. 281-294.

- Ђорђевић, Ивица и Јефтић, Зоран. „Промена финансијског положаја државе као безбедносни проблем“, Међународни проблеми, Vol. LXVIII, No.2-3, 2016, стр. 193-208.

- EBRD, Life in Transition, After the Crisis. European Bank for Reconstruction and Development, London, 2011. 
- ILO, Sectoral impact, responses and recommendations, International Labour Organization, Genève, 2020. https://www.ilo.org/global/topics/coronavirus/sectoral/lang--en/index.htm

- Maxmen Amy \& Tollefson Jeff, „Two decades of pandemic war games failed to account for Donald Trump", Nature Research, 04 August 2020, Springer Nature Limited, https://www.nature.com/articles/d41586-020-02277-6

- Милановић, Бранко, Глобална неједнакост, Академска књига, Нови Сад, 2016.

- Министарство Финансија Републике Србије, ТЕКУЋА МАКРОЕКОНОМСКА КРЕТАҢА, Септембар $2020 . \quad$ https://www.mfin.gov.rs/wpcontent/uploads/2020/09/prezentacija_novo_sr-pdf.pdf

- НБС, Извештај о инфлацији, август 2020, Народна банка Србије, https://www.nbs.rs/internet/cirilica/90/ioi.html

- OECD, Tackling Coronavirus (COVID-19) - Contributing to a Global Effort, The COVID19 Crisis in Serbia, Organisation for Economic Co-operation and Development, https://www.oecd.org/coronavirus/en/\#country-tracker

- Popkin M. Barry, Adair S. Linda and Ng Wen Shu, „Global Nutrition Transition: The Pandemic of Obesity in Developing Countries", Nutrition Reviews, Volume 70, Issue 1, 1 January 2012, Pages 3-21, https://academic.oup.com/nutritionreviews/article/70/1/3/1829225

- Reinhart Carmen \& Reinhart Vincent, „The Pandemic Depression The Global Economy Will Never Be the Same“, Foreign Affairs, September/October 2020, Council on Foreign Relations, https://www.foreignaffairs.com/articles/united-states/202008-06/coronavirus-depression-global-economy

- Smart kolektiv i Forum za odgovorno poslovanje, Posledice pandemije korona virusa na poslovanje malih i mikro preduzeća u Srbiji, Beograd, 2020., str. 4-7, https://smartkolektiv.org/aktuelnosti/analiza-posledice-pandemije-na-poslovanjemikro-i-malih-preduzeca-u-srbiji/

- Тањуг, „Европол: У време корона кризе расту криминал и педофилија“, Новости, 2.4.2020, https://www.novosti.rs/vesti/planeta.299.html:856876Evropol-U-vreme-korona-krize-rastu-kriminal-i-pedofilija.

- UN, HUMAN SECURITY HANDBOOK - An integrated approach for the realization of the Sustainable Development Goals and the priority areas of the international community and the United Nations system, United Nations - Human Security Unit, New York, 2016.

- UNCTAD, Trade and Development Report 2018 / Report by the secretariat of the United Nations Conference on Trade and Development, United Nations, New York and Geneva, 2018.

- UNDP, Human Development Report - New Dimensions of Human Security, Oxford University Press, New York - Oxford, 1994. 


\title{
CONSEQUENCES OF THE COVID 19 PANDEMIC ON THE ECONOMIC SECURITY OF THE CITIZENS OF THE REPUBLIC OF SERBIA
}

\begin{abstract}
It is still too early for a final analysis of the course of the pandemic and its consequences, but we can already talk about the visible effects of the state of emergency on the quality of life of citizens and the level of economic activities. As an analytical framework, we will use the concept of human security, which deals with the issue of security of citizens through the analysis of seven areas important for the quality of their lives. In each of the seven dimensions of human security, certain changes have happened, directly or indirectly. Second only to health dimension, the most visible effects are in the economic dimension, which is the focus of our analysis. Due to the developed methodology and the way of data processing, the effects of the pandemic are first registered through the change of economic indicators for which the most extensive statistical sources are available. We can talk about environmental aspects in a positive context, while political, and community security, ie. individual security, in addition to linking with health effects, can be contextualized in relation to the situation before the pandemic. There is an interesting correlation in these areas with respect to previous situations and in the political sphere practice, ie community security. Linking the previous with the current situation tells us about the shortcomings in the field of human security, which in certain circumstances can contribute to a drastic worsening of the situation.
\end{abstract}

Keywords: pandemic, Covid 19, human security, economy, quality of life. 